\title{
WHY I AM NOT A BRAZILIANIST: A CONVERSATION WITH ROBERT STAM
}

\section{Adalberto Müller* \\ Ramayana Lira de Sousa**}

\section{Do you consider yourself a Brazilianist?}

I find that there is a frequent confusion in Brazil which views any non-Brazilian who writes about Brazil a "Brazilianist."

In my case, I reject the label, and not only because during the dictatorship it became a pejorative term for scholars in the social sciences who had access to Brazilian archives in a way that was not available to Brazilians.

I am not a Brazilianist, but rather a comparatist formed in comparative literature.

My majors were more Anglo-American and French than Brazilian. The professors of Brazilian literature at that time were horrible, one was an American who defended Portuguese colonialism, another an American who trained with the proto-CIA and whose idea of teaching was to correct the students for their faulty liaison when the read poems in Portuguese. If I were a Brazilianist, I would speak better Portuguese, since I never studied Portuguese formally but learned it through reading, listening to Brazilian music, and through my convivencia with the Brazilian communities first in Paris, then in Berkeley, then in Brazil itself, then in New York.

I have published some 18 books and anthologies, only two (Brazilian Cinema and Tropical Multiculturalism) have to do exclusively with Brazil, although a number of other books deal with the triangle Brazil-France-US (the case of Flagging Patriotism and Race in Translation). What I do in all my books, except for the Truffaut book (Truffaut and Friends: Modernism, Sexuality, and Adaptation), is systematically include Brazil in everything I do - Cervantes and Fielding next to Machado de Assis; Mario de Andrade next to James Joyce; Oswald de Andrade next to Alfred Jarry, Roberto Schwarz next to Fredric Jameson; Ismail Xavier next to Gilles Deleuze - tudo em pé de igualdade. There is something colonizing about the idea of the Brazilianist. For example, I write about la chose française - and I studied French and French literature much, much more than I studied Portuguese, and I formally studied French literature and culture in France - but no French person calls me a Frenchicist, because the assumption is that France is inherently interesting, whereas an interest in Brazil has to be explained, with the eternal question: How did you become interested in Brazil? i.e. there must be an explanation: I fell in love (true); I heard Jobim and João Gilberto

\footnotetext{
* Professor de Teoria da Literatura e de Literatura e Cinema na Universidade Federal Fluminense (UFF). E-mail: adalbertomuller@gmail.com.

** Professora do Programa de Pós-Graduação em Ciências da Linguagem da Universidade do Sul de Santa Catarina. E-mail: ramayana.lira@gmail.com.
} 
(true); I love Jorge Amado (mais ou menos) etc. No, Brazil is inherently very interesting!

My son and I, when he is in US, like to make fun of this idea. When the New York subway is late: we say: "O que você quer? É tecnologia Americana... nada funciona"

Let's talk about the eighties. Can you describe the field of film studies at that time? I understand that most of film scholars at that time came from literary studies, is it right?

First of all, the definitive book on the history of the field is by my colleague Dana Polan, Scenes of Instruction: the beginnings of the U.S. study of film (University of California Press, 2007).

I got my job in cinema studies in 1977, after studying literature comparada (Anglo-American, Brazilian-Portuguese and Lusophone, and French and Francophone). I applied for jobs in all my areas - English, French, Portuguese, Comp Literature and film. Thank God I got a New York job in film, thanks to knowing a lot about film due to my two years dodging the Vietnam War draft in Tunisia - where I had the time of my life and became fluent in French and schwoya barak Arabic - followed by a year studying at the Sorbonne, where I met my wife Gilda Penteado. I arrived in France a few months after May 68 (in September) and joined anti-war demonstrations and got beat up by the CRS (CRS-SS was the slogan) so I can honestly say I was beat up by fascist police. In France I studied French literature and history but spent most of my time attending multiple sessions at the Cinematheque and reading about film theory.

I realize I totally digressed from your question.

When I got my job at NYU, I think I was the last of a disappearing breed literature students getting jobs in film. The field was already being professionalized since there were already many film studies departments in the US, affiliated variously with literature depts. Or journalism, or filmmaking etc

Your PhD dissertation, published as Reflexivity in Film and Literature (UMI Press, 1985), was published first in Brazil in 1981, as $O$ Espetáculo interrompido (by Paz \& Terra). Why Brazil?

It was published in Portuguese because Walnice Galvão was staying with us in Berkeley and happened to read it and liked it and recommended it to Paz e Terra. I am very grateful to her because I was a perfectionist and would have waited a long time to publish my first book out of caution and insecurity. The good reception in Brazil encouraged me and gave me confidence.

The good reception of the book was despite the translation, which I didn't check and which had many errors - e.g. "shot of Scotch" (dose de whiskey) was translated as "filmagem na Escócia"

By the way, a decade earlier, in 1971 I published one of my first essays - on the subversive aesthetics of Godard - in the Suplemento Literário do Estado de Sao Paulo. 
Apparently some readers assumed I was Brazilian and were asking how come they hadn't met me.

A further irony is that I discovered much much later that the dictatorship's censors had plagiarized my book - but within an opposite intention - i.e. a guide on how to detect and censor a subversive film. I recognized my paragraph about Godard's films sending the spectators senses in contradictory directions in the censors's prose.

In the late eighties, Mikhail Bakhtin becomes a decisive reference to your work. Do you think that Bakhtin was important to the shifting from structuralism/post-structuralism to the stress on culture issues?

Absolutely. I see him as a proto-post-structuralist, who, already in the late 1920s, predicted both the emergence of structuralism and its critique, decades before Derrida. If you note the intellectual trajectories of people like Laura Mulvey, Fredric Jameson, Homi Bhabha and many others, you will find that Bakhtin was a destabilizer of binarisms and of Althusserian-Lacanian Marxism and triggered moves in the direction of multiplicity and dialogism. When I teach Bakhtin I point out that he is not a systematic thinker and that it is more or less meaningless to call oneself a Bakhtinian - I see his work more as a leaven, an opener, a catalyst as part of one's personal collage of thinkers and trends.

How do you think your work at that period can be compared to the raising of cultural studies in U.K.?

I have written about this. There is a certain narrative that traces all cultural studies to Birmingham. I find this very limited and anglocentric, because for me it was not a point of origin - much as I liked much of the work - but just one more transtextual turn for someone who had read people like James Baldwin, Leslie Fiedler, Frantz Fanon, Roland Barthes, Antonio Candido, Roberto Schwarz, Glauber Rocha, Oswald and Mario de Andrade. In one essay I suggested that cultural studies could be traced to Mario and Oswald, and also Roger Bastide, and not necessarily to Hoggart etc etc. I don't say this out of Anglophobia - after all I dedicated much of my academic life to studying English literature - but out of transnational fairness. Another partial truth is: British cultural studies is left political; American is liberal apolitical. One cannot exaggerate the role of African American writers in foregrounding intersectionalities (Crenshaw) or race, class, gender, sexuality, and empire. It is really a false divide and one can love both, just as one can love Roberto Schwarz and the Campos Brothers, Caetano and Chico, Rio and São Paulo.

The Birmingham group learned a lot about race from African Americans, and Americans learned about Gramsci from the British.

Unthinking Eurocentrism was first published in 1994 and represented an extraordinary contribution for the debate regarding the complicity between 
Eurocentrism and mass media and the necessity of a multicultural approach. 20 years later, is there any other way to "unthink" Eurocentrism?

Wow - that's too big a question, and in a way Ella and I answered it when we were asked to do a $20^{\text {th }}$ anniversary new edition, which came last year with a long afterward answering that very question.

We acknowledge that today we probably wouldn't use the word multiculturalism actually we preferred polycentrism - since it has been attacked both by the right (who see it as politically correct, Marxist, leftist etc) and by the left, who consider it cooptative mild liberalism.

We discuss the political side of these issues in two recent books, Flagging Patriotism (a pun, as usual) which was basically a diatribe against Bush/Cheney and their wars (which bequeathed us ISIS) but which also denounced the idea of political correctness - an invention of George Bush Sr to discredit any movement against racism, sexism, homophobia etc.

A more important book - since directly political books like Flagging get outdated very quickly - was our 2013 book Race in Translation: Culture Wars in the Postcolonial Atlantic - which talks about a certain right-left convergence, where both the right (Cameron, Sarkozy, Merkel, Finkelkraut) and the left (Bourdieu-Wacquant, Zizek) all hate multiculturalism and identity politics. We talk about why that might be, and explain that Zizek might be progressive and radical in many ways, but when he talks about multi-culture and anti-racist movements he sounds exactly like a rightwinger like Denesh de Souza.

But that is perhaps the least interesting aspect of the book, which is really a kind of attempt at a discursive history of post-war intellectuals in Brazil, France, and the US, in so far as they addressed issues of colonialism/postcolonialism, race, cultural identity etc. It is a plaidoyer against the national narcissism and provincialism which sees issues only through a national grid, without seeing transnational connectivities of the Black Atlantic, the Red Atlantic (indigenous movements etc). We downplay multiculturalism as a term but elaborate and expand on the idea of eurocentrism - not the best term, since it tempts people to think we are anti-Europe, when we are only against Western domination in general. In Europe they introduce us sometimes by saying: "Although they are against Europe, they love Godard and Truffaut" - a complete misunderstanding. We thought the book had no echo, and never found its audience because the title didn't signal that it could be of interest to Brazilians, French, North Americans, diasporics etc.

I would love to publish it in Portuguese, but modified for a Brazilian audience and updated.

I [Adalberto Muller] think the emphasis on translation theory as a conceptual device and the question of reflexivity is decisive to understand your position in the field of adaptation studies. Do you agree?

I agree completely. I recently realized that I can sum up my affinities and trajectory through a palimpsestic series of trans-words: comparative literature and 
translation; Bakhtin and translinguistics; Genette and transtextuality; my approach in the most recent book (Keywords in Subversive Film/Media Aesthetics) is transartistic, i.e. bringing in all of the cinema's sister arts of music, theatre, painting etc.

Looking through the index of terms in Keywords, I see the following terms: transfiguration, transmogrification (Coleridge), transvaluation (Nietzsche), transgenerational (an indigenous critique of modernist Oedipalism), transhistorical fusion (Benjamin and Glauber Rocha), transindividual subjectivity, transmedia story telling (Jenkins, Gaudreault), transnational allegory, transpersonal time, transnational allegory, transpersonal time, transracialized classics (Welles's Voodoo Macbeth, Zé Celso's Hamlet) transvestitism (Bakhtin). Also Rocha's Trance-Brechtianism, which goes beyond Brecht via transe and candomblé. (I grew up next to a Pentecostalist Church in New Jersey where people literally went into trance and spoke in tongues, so much later candomblé seems somehow familiar).

On reflexivity, it is a longstanding concern. It explained my pleasure in reading Cervantes, Fielding and Machado de Assis (ludic reflexivity), my delight in Père Ubu and the Rei da Vela (aggressive avant-garde reflexivity or anti-illusionism) and my respect for Brechtian reflexivity (didactic reflexivity). The schema happens to recapitulate the life cycle of childlike pleasure, adolescent rebellion, and pedagogical maturity.

However, my view of reflexivity has changed, and my view of adaptation has evolved, but in directions that were there from the beginning.

When I wrote my dissertation, which became $O$ Espetáculo Interrompido, I was kind of a Bakhtinian/Brechtian - here a nod to my fellow Bakhtinian carnivalizer João Luiz Vieira -- full of the typical leftist readings of the time (Brecht, Althusser, Macheray, Goldman, Jameson etc). After all, I went from Tunis in 66, to Paris in 68/69 to Berkeley in 69 to 77, all hotspots of leftist and anti-imperialist activism.

I remember after one class I taught as a graduate student in Berkeley, a student came up and told me: "Your course transformed me completely: all those films I used to love I now hate!" And I started to wonder if my mission in life was to make people hate films.

In the end, I think it was a misunderstanding of Brecht, who actually believed in intelligent entertainment not in austere, puritanical art.

In 73-74 I went again to Paris and studied with Marie Clair Ropars at Vincennes, and she invited me to participate in a book on Brazilian cinema, which became a coauthored essay with Maria Rosa Magalhães that appears in Raquel Gerber's Glauber book. When I returned from Paris in 1974, through a lucky coincidence, Glauber Rocha, who was close to Coppola and to Tom Luddy of the Pacific Film Archives, came to live with me, just as I was writing on Terra em Transe. He explained who the prototypes were for the characters: Paulo Martins was based on himself plus a number of leftist intellectuals and four journalists from Jornal do Brasil; Porfirio Diaz, on Carlos Lacerda and other chameleonic politicians; Vieira, on Miguel Arraes and other leftist politicians. He told me that he personally had the same conversation as Paulo Martins and Vieira: “o nosso líder! O nosso grande líder?” In Algeria, I served as translator for his volcanic 
commentaries after film screenings. Glauber, with all his eccentricities, was one of the most decolonized people I have ever met.

I now like reflexivity but I feel it has been coopted and has lost its critical edge. In a theorist like Bourdieu, even though I respect him a lot for repoliticizing French intellectual life, and use many of his concepts, reflexivity itself becomes a form of cultural capital. I, the social scientist, am reflexive and I can explain to you, masses, why you should understand your situation better. (Sorry, Bourdievians)

\section{How did a gringo become anti-imperialist? How did a cara-pálida become an anti-racist and a pro-indigenist person?}

I can't explain that without explaining my freakishly strange family. My parents were children of Dutch immigrants, but I also go back to French Huguenots. (Thus the uncanny fact that I ended up writing about Jean de Lery and La FrancAntartique!) My mother was working class with an $8^{\text {th }}$ grade education but very smart and in love with ideas. My grandfather was a carpenter and my father a lawyer, by accident. Although they didn't know anything about the American educational system (they often spoke Dutch to each other), we were seven children and my oldest brother was a child prodigy who finished high school early; Princeton heard about him an offered him a scholarship in chemistry. The rest of us then followed him into the academe, ultimately leading to a family with $6 \mathrm{PhDs}$.

Why does that explain my politics?

I learned Marxism from my brother Jim who studied philosophy in Vienna and then did a PhD at Brandeis with Herbert Marcuse; I learned anti-imperialism from my brother John/Juan who became a liberation theologian in Central America, who studied in Basel and Tubingen, and write en espanhol, and who explained imperialism in Latin America when I was 10. I learned anti-racism from my parents who were simply not racist, rather than anti-racist, as if the idea of racism had never occurred to them, and from witnessing racism in New Jersey, and then participating (marginally) in the Civil Rights movement. I learned anti-colonialism in North Africa where I lived and taught while reading Fanon and Malcolm X and Retamar, and then I went to Paris, with everything that one could learn there. (So I have a very suspicious collection of passport entries, which even include Prague during the Prague spring - I am extremely ancient). I decided to go to Berkeley after seeing Agnes Varda's film about the Black Panthers, and I got later to meet Kathleen Cleaver and tell her the story.

You have always been interested in music. Could you talk about your experience with Brazilian music?

Wow! This gets to the heart and soul of things. Brazilian music is my ambulatory audiotopia (Josh Kun), my emotional home. In my office, I listen to Brazilian music as I work and it both energizes me and calms me and rehumanizes me in the middle of petty academic crises. I start every Brazilian Cinema class with a music video to set the mood and pace and the theme, since Brazilian music talks about everything from slavery to 
the Internet. I start the class with Manyata by Caetano, where I sumperimpose the song on digital images of Manahatta, the Indian name for Manhattan (in a digital reconstruction of Manhattan before European arrival) since I have found that often both Brazilians and Americans do not realize the song is about New York. I have written a long unpublished analysis of that poem/song. After that, in my course, Pixote is coupled with "Haiti" one of the most powerful poem-songs about police brutality. Films about Slavery? Gilberto Gil's "Quilombo", Elis Regina singing "O Morro". With Sao Paulo $S / A$, I show the music video of "Sampa". City of God and Gabriel Pensador or Racionais $\mathrm{MC}$, etc etc. Films about the coup d'etat. "Apesar de Você", and street activism. Milton Nascimento's "Nos Bailes da Vida". My partner Ella, who speaks Portuguese without an accent - how I envy her! -, but with lots of mistakes, and who knows the lyrics of "A Banda" and many other songs, and who sambas to the point of a samba expert exclaiming "Ela e negra!", always sings "Apesar de voce" as a fortifying song when she is involved in some political battle.

Brazilian music also has a very personal utopian meaning for me. Two of my older brothers (Jim and David) play classical music - piano and bassoon respectively and are very knowledgable about classical music. They even paid me to listen to them lecture about classical music, initiating me into pianissimos and codas and fugues etc, because they thought I was dangerously close to loving jazz and popular music too much. Jim used Thelonius Monk as a bridge, saying that he was classically trained, but I still loved my popular, largely black music and jazz. I went to the clubs in New York where Dizzy Gillespie, Olatunji, Thelonious Monk, Nina Simone and many others played. So Brazilian music gave me the answer to my brothers' high cultural capital investment in classical music - they could hear 3 notes and say which symphony orchestra was playing Mozart - since Brazilian popular music is erudite and popular, where o povão dances to Chico's erudite language, or to Caetano's "Haiti", where Caetano in "Lingua" rifs on Heidegger- spräche "only philosophize in German" (my brother, who knows Greek and German, literally told me, that I couldn't really understand Heidegger without knowing Greek and German) - but Caetano says if you have a great idea, put it in a song. By the way, the best answer to Heidegger worship is João Carlos Rodrigues' answer - reported to me by Ismail Xavier - to a Brazilian who returned to Rio and pronounced himself a Heideggerean, to which Joao Carlos replied: "neste calor?"

My son Giba was dubbed "Caetano" in his Paulistano colégio, and now dabbles with guitar and sings "de noite na cama, fico pensando." When I gave a little course in UFBA, the students sang that song, so after being introduced I sang: "De noite, na mesa, fico falando".

Brazilian music at its best is sensuous, percussive, smart, allusive, post-post. You always know what Caetano is reading when he writes. I think he was reading Marshal Berman when he wrote "o poder de grana que constrói e destrói coisas belas".

Only Brazil, to my knowledge has produced a literary-critic genius and musician like Ze Miguel Wisnik, incredible musicians like Guinga and Gismonti.

You guys made me want to write a memoir. I didn't know it was so easy. 